\title{
KEPEMIMPINAN KHARISMATIK GURU DALAM PEMBELAJARAN PENDIDIKAN ISLAM DI SEKOLAH
}

Oleh:

Erfendi $^{204}$

\begin{abstract}
Abstrak
Kepemimpinan (leadership) adalah kemampuan seseorang (pemimpin atau leader) untuk mempengaruhi orang lain (orang yang dipimpin atau para pengikut), sehingga orang lain tersebut bertingkah laku sesuai dengan apa yang dikehendaki oleh pemimpin. Peranan pemimpin sangat menentukan pendidikan yang dilaksanakan di sekolah karena sekolah berfungsi untuk meneruskan nilai-nilai luhur bangsa kepada generasi muda serta berlangsungnya proses pembelajaran. Pemimpin dalam suatu lembaga pendidikan sangat menentukan arah menuju perbaikan pengelolaan madrasah.Tipe pemimpin yang memiliki kharismatik sangat diperlukan dalam meningkatkan kualitas pengelolaan madrasah.Dalam suatu lembaga pendidikan kepemimpinan kharismatik diharapkan dapat memberikan arah kepada semua anggota dalam mencapai tujuan organisasi. Oleh karena itu, Sangat diperlukan seorang pemimpin berkharismatikyang mampu meningkatkan kualitas Pengolaan Pendidikan Di Madrasah.
\end{abstract}

\section{Kata Kunci: Kepemimpinan, Kharismatik .}

\section{Pendahuluan}

Pengelolaan pendidikan tidak terlepas dari manajemen kepala madrasah yang tidak dapat dipisahkan dari kepemimpinan yang diadopsi kepala madrasah dalam menjalankan perannya sebagai seorang "leader". Hal ini disebabkan oleh adanya keterikatan yang kuat antara kepemimpinan (leadership) yang dipakai oleh kepala madrasah dengan keefektifan secara keseluruhan dari proses pendidikan di madrasah. Pendapat ini pada dasarnya berakar pada konsep kepemimpinan pendidikan yang bermuara pada pembentukan dan pengembangan secara menyeluruh potensi manusia (warga madrasah) melalui penggunaan yang efektif akan sumber daya

${ }^{204}$ Dosen Tetap Program Studi Pendidikan Agama Islam STAI Auliaurrasyidin Tembilahan Kabupaten Indragiri Hilir Provinsi Riau

140 
organisasi, pengetahuan dan ketrampilan kepemimpinan. ${ }^{205}$ Disamping itu, kekomplekan tantangan-tantangan yang dihadapi oleh madrasah pada saat sekarang ini seiring semakin kompleksnya masyarakat mengharuskan keberadaan suatu kepemimpinan yang dapat membantu madrasah dalam mengembangkan batas-batas dan fungsi-fungsi tradisionalnya. ${ }^{206}$

Lembaga pendidikan berperan sebagai wahana strategis dalam mempersiapkan sumber daya manusia yang berkualitas atau bermutu untuk pembangunan bangsa dan negara. Lembaga pendidikan di Indonesia turut serta memberikan kontribusi yang besar, sehingga di harapkan tercipta sumber daya manusia yang bertaqwa, beriman, menguasai tekhnologi untuk memelihara eksistensi negara. Oleh karena itu, peran Madrasah sebagai salah satu lembaga pendidikan yang bercirikan khas Islam mampu menguasai ilmu pengetahuan dan kemampuan manajerial kependidikan guna mencapai efektifitas lembaga pendidikan Islam. ${ }^{207}$

Peranan pemimpin sangat menentukan pendidikan yang dilaksanakan di sekolah karena sekolah berfungsi untuk meneruskan nilainilai luhur bangsa kepada generasi muda serta berlangsungnya proses pembelajaran. ${ }^{208}$ Pimpinan lembaga pendidikan Islam haruslah mendesain format pendidikan yang kompetitif dan inovatif untuk keperluan masa depan. Hanya dengan kesiapan manajemen pendidikan yang efektif, lembaga pendidikan Islam dapat merespon perubahan sehingga tidak akan mengalami stagnasi (kemacetan) dan ketinggalan dalam dinamika perubahan yang cepat.

${ }^{205}$ D.L.Weller, Quality Human Resources Leadership : A Principal's (Maryland: The Scarecrow Press, 2000), h.29

${ }^{206}$ Green,RL, Practicing the Art of Leadership : Problem based Approach to Implementing The ISLLC Standars (Colombus, Ohio: Merrill Prentice Hall, 2001), h.138

${ }^{207}$ Syafaruddin, Manajemen Lembaga Pendidikan Islam (Jakarta: PT.Ciputat Press, 2005), h. 1

${ }^{208}$ Syafrida, Kepemimpinan Kepala Sekolah, Manajer Pendidikan, Vol.9 No.5 (2015) h. 679-685 
Pemimpin dalam suatu lembaga pendidikan sangat menentukan arah menuju perbaikan pengelolaan madrasah.Hal itu hanya dapat dicapai jika kepala madrasah beserta stafnya menjalankan manajemen yang fungsional dengan kepemimpinan partisipatif dalam pengambilan kebijakan dalam setiap lembaga pendidikan.Tipe pemimpin yang memiliki kharismatik sangat diperlukan dalam meningkatkan kualitas pengelolaan madrasah.Dalam suatu lembaga pendidikan kepemimpinan kharismatik diharapkan dapat memberikan arah kepada semua anggota dalam mencapai tujuan organisasi.Oleh karena itu, Sangat diperlukan seorang pemimpin yang mampu meningkatkan kualitas Pengolaan Pendidikan Di Madrasah

Berangkat dari latar belakang diatas maka rumusan masalah pada penulisan karya ilmiah ini yaitu membahas, 1) Kepemimpian, 2) Konsep Kharismatik, 3) Kepemimpinan Karismatik, 4) Implikasi kepemimpinan karismatik di Madrasah, dan 5) Manfaat bagi Madrasah.Tujuan pembahasan ini adalah untuk memerikan kontribusi pada pemaca mengenai kepemimpinan, konsep kharismatik, kepemimpinan kharismatik, implkasi kepemimpinan kharismatik di madrasah dan manfaat bagi marasah.

\section{Pengertian Kepemimpinan}

Definisi kepemimpinan (leadership) adalah kemampuan seseorang (pemimpin atau leader) untuk mempengaruhi orang lain (orang yang dipimpin atau para pengukut), sehingga orang lain tersebut bertingkah laku sesuai dengan apa yang dikehendaki oleh pemimpin. ${ }^{209}$

Managerial leadership assumes that the focus of leaders ought to be on functions, tasks and behaviours and that if these functions are carried out competently the work of others in the organisation will be facilitated. Most approaches to managerial leadership also assume that the behaviour

${ }^{209}$ Soerjono Soekanto, Sosiologi Suatu Pengantar (Jakarta: Raja Grapindo Persada, 2006), h. 288.

\section{2}


of organisational members is largely rational. Authority and influence are allocated to formal positions in proportion to the status of those positions in the organisational hierarchy. ${ }^{210}$

Kepemimpinan itu merupakan fenomena interaksi sosial yang kompleks dan sering kali sulit dibaca.Karena itu, sebelum berdiskusi lebih jauh tentang pemimpin dan kepemimpinan, berikut ini disajikan beberapa definisi, menurut Pramuji kepemimpinan merupakan terjemahan dari kata Leadership yang berasal dari kata leader.Pemimpin (leader) adalah orang yang memimpin, sedangkan pimpinan merupakan jabatannya. Dalam pengertian lain, secara etimologi istilah kepemimpinan berasal dari kata dasar "pimpin" yang artinya bimbing atau tuntun. Dari "pimpin" lahir kata kerja "memimpin" yang artinya membimbing dan menuntun. Menurut Robbins, kepemimpinan adalah kemampuan untuk memengaruhi sekelompok anggota bekerja mencapai tujuan dan sasaran. Sumber dari pengaruh dapat diperoleh secara formal, yaitu dengan menduduki suatu jabatan manajerial yang didudukinya dalam suatu organisasi.

Fiedler berpendapat, "Leader as the individual in tehe group given the task of directing and coordinating task relevan group activities". Dari pengetian tersebut menunjukan bahwa seorang pemimpin adalah anggota kelompok yang memiliki kemampuan untuk mengarahkan dan mengoordinasikan kinerja dalam rangka mencapai tujuan. Fiedler dalam hal ini lebih menekankan pada "directing and coordinating". ${ }^{211}$

Oteng Sutisna mengemukakan bahwa kepemimpinan adalah kemampuan mengambil inisiatif dalam situasi sosial untuk menciptakan bentuk dan prosedur baru, merancang dan mengatur perbuatan, dan dengan

${ }^{210}$ Tony Bush, Educational leadership and management: theory, policy, and practice, South African Journal of Education, Vol 27(3), h. 391-406

${ }^{211}$ Imam Machali dan Ara Hidayat, The Handbook of Education Managemant, (Jakarta: Perdana Grup, 2016), h. 83 
berbuat begitu membangkitkan kerja sama ke arah tercapainya tujuan. ${ }^{212}$ Peter G.Northouse menyatakan bahwa kepemimpinan secara singkat adalah proses dimana individu memengaruhi sekelompok individu lain untuk mencapai tujuan bersama. ${ }^{213}$ Menurut Joseph C.Rost kepemimpinan adalah sebuah hubungan yang saling mempengaruhi antara pemimpin dan pengikut (bawahan) yang menginginkan perubahan nyata yang mencerminkan tujuan bersamanya. ${ }^{214}$

Berdasarkan pendapat beberapa tokoh di atas maka dapat disimpulkan bahwa kepemimpinan adalah setiap tindakan atau perbuatan yang dilakukan oleh individu atau kelompok untuk mengkoordinasi dan memberi arah kepada individu atau kelompok yang tergabung di dalam wadah tertentu untuk mecapai tujuan yang telah ditetapkan sebelumnya.

\section{Konsep Karismatik}

Konsep tentang kepemimpinan erat kaitannya dengan kekuasaan dan wewenang. Kekuasaan (power) adalah setiap kemampuan untuk mempengaruhi pihak lain, sedangkan wewenang (autority) adalah kekuasaan yang ada pada seseorang atau sekelompok orang yang mempunyai dukungan atau mendapat pengakuan dari masyarakat. Penggunaan wewenang timbul tatkala masyarakat mulai mengatur pembagian kekuasaan dan menentukan penggunaannya.Maka kekuasaan tanpa wewenang disebut sebagai kekuatan yang tidak sah.Kekuasaan harus mendapatkan pengakuan dan pengesahan dari masyarakat yang di sebut sebagai wewenang.

${ }^{212}$ Sudarwan Danim, Kepemimpinan Pendidikan, (Bandung: Alfabeta, 2010) h. 6

${ }^{213}$ Peter G.Northouse, Kepemimpinan Teori dan Praktik, (Jakarta:Indeks, 2016) h. 5

214 Triantoro Safaria, Kepemimpinan, (Yogyakarta:Graha Ilmu,2004). h. 5

\section{4}




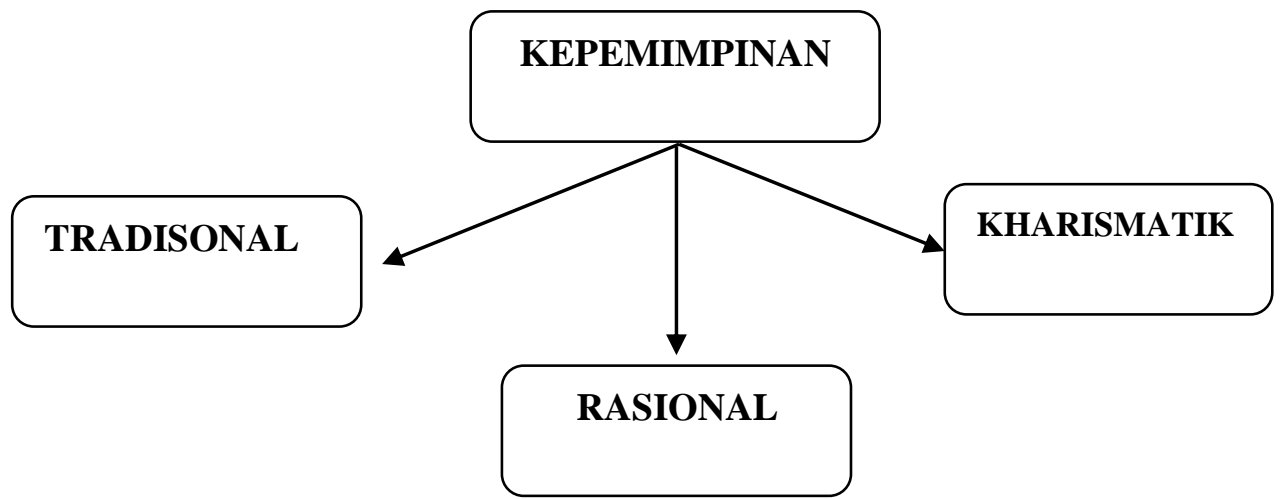

Gambar 1.1 konsep kepemimpinan dan wewenangnya Max Weber

Max Weber membagi kepemimpinan dan wewenangnya menjadi tiga: tradisional, rasional dan karismatik. ${ }^{215}$ Pengertian pertama, pemimpin tradisional mendapatkan wewenangnya di masyarakat berdasarkan ketentuan-ketentuan di masyarakat secara tradisional.Biasanya berkaitan dengan hubungan kekeluargaan, atau didapat secara turun temurun berdasarkan tradisi yang diwarisi, seperti raja.

Kedua, pemimpin rasional adalah kepemimpinan yang wewenangnya didasarkan pada hukum dan kaidah-kaidah yang berlaku dan ditaati oleh masyarakat.Pada masyarakat yang menerapkan nilai-nilai demokratis, biasanya pemimpin yang mendapatkan kekuasaan diberi kedudukan menurut jangka waktu tertentu dan terbatas. Wewenang rasional biasa disebut sebagai wewenang absah atau legal atau bikorasi.Contohnya seperti presiden, perdana menteri, gubernur, bupati, dan camat.

Ketiga, pemimpin karismatik yaitu didasarkan pada seseorang yang mempunyai kemampuan khusus yang didapatkan karena anugrah.Wewenang ini tidak diatur oleh kaidah-kaidah tradisional dan rasional, bahkan sifatnya cenderung irasional. Adakalanya wewenang karismatik bisa hilang dari seorang pemimpin manakala masyarakatnya

${ }^{215}$ Ibid., h. 280-285 
sendiri telah berubah dan mempunyai faham yang berbeda. Dan karisma bisa saja bertahan dan bahkan meningkat sesuai dengan individu yang bersangkutan membuktikan manfaat bagi masyarakat dan pengikutpengikutnya akan menikmatinya.

Istilah karisma berasal dari kata yunani yang berarti karunia (gift), anugerah atau pemberian.Karis berarti menyukai, merujuk kepada kepribadian seseorang yang memiliki kepribadian menarik ataupun memiliki daya pikat mempunyai penampilan menarik atau mampu berkomunikasi. Sehingga banyak orang yang menyukainya. ${ }^{216}$ Artinya orang yang memiliki karisma berarti orang yang memiliki kelebihan, perbedaan dan keistimewaan dari pada yang lain.

Karisma merupakan kemampuan khusus (wahyu, pulung, nubuah, keramat) yang ada pada diri seseorang.Kemampuan khusus ini melekat karena anugrah dari Tuhan.Orang-orang di sekitarnya mengakui kemampuan tersebut atas dasar kepercayaaan dan pemujaan, karena mereka menggangap bahwa sumber kemampuan tersebut berada di atas kemampuan dan kekuasaan manusia pada umumnya. Masyarakat akan masih mempercayai karismatik seseorang selama hal tersebut terbukti keampuhan dan maanfaatnya bagi masyarakat. Contohnya nabi, rasul, raja dan para pemimpin yang terkemuka sepanjang sejarah. ${ }^{217}$

Setidaknya ada beberapa ciri yang menunjukkan karismatiknya kepemimpinan seseorang. ${ }^{218}$ Diantaranya memiliki kepekaan yang tinggi terhadap masalah artinya pemimpin tersebut faham dengan situasi, ia percaya diri sehingga mampu mempengaruhi orang lain secara luar biasa dan tidak mudah terpengaruh dengan orang lain.

${ }^{216}$ Alfian, M. Alfan. Menjadi Pemimpin Politik. (Jakarta: Gramedia Pustaka Utama, 2009) h. 140.

${ }^{217}$ Soerjono Soekanto, Sosiologi Suatu Pengantar, (Jakarta: Raja Grapindo Persada, 2006), h. 282.

${ }^{218}$ Ibid, h. 282

\section{6}


Pemimpin yang berkarisma cenderung menciptakan efek mitologis, supranatural dan berbagai kejadian ajaib sehingga menarik orang awam untuk mengkultuskan dan bahkan sampai memujanya. Pemimpin yang karismatk bagi kebanyakan orang Indonesia seperti sang ratu adil yang ditunggu kedatanganya untuk memperbaiki keadaan, atau menurut kepercayaan dari orang yahudi bagaikan Mesies, atau umat nasrani yang mempercayai hadirnya Yesus sang juru selamat yang muncul dari Nazaret. $^{219}$

Jadi dapat disimpulkan bahwa konsep kepemimpinan yang ditawarkanmax waber itu ada tiga yaitu tradisional, rasional dan karismatik.Dan kepemimpinan karismatik dapat diartikan sebagai kemampuan menggunakan keistimewaan atau kelebihan sifat kepribadian dalam mempengaruhi pikiran, perasaan dan tingkah laku orang lain, sehingga dalam suasana batin mengagumi dan mengagungkan pemimpin bersedia berbuat sesuatu yang dikehendaki oleh pemimpin.

1. Indikator Karisma

Bukti dari kepemimpinan karisma diberikan oleh hubungan pemimpinpengikut.Seperti dalam teori awal oleh House (1977), seorang pemimpin yang memiliki karisma memiliki pengaruh yang dalam dan tidak biasa pada pengikut. Para pengikut merasa mereka bahwa keyakinan pemimpin adalah benar, mereka bersedia mematuhi pemimpin, mereka merasakan kasih saying terhadap pemimpin, secara emosional mereka terlibat dalam misi kelompok atau organisasi, mereka memiliki sasaran kinerja yang tinggi, dan mereka yakin bahwa mereka dapat berkontribusi terhadap keberhasilan dari misi itu.

${ }^{219}$ Alfian....Op.cit h. 142 . 


\section{Ciri dan Perilaku}

Ciri dan perilaku merupakan penentu penting dari kepemimpinan karismatik. Para pemimpin karismatik akan lebih besar kemungkinannya memiliki kebutuhan yang kuat akan kekuasaan, keyakinan diri yang tinggi dan pendirian yang kuat dalam keyakinan dan idealism mereka sendiri. Perilaku kepemimpinan dan perilaku dari pengikut antara lain: ${ }^{220}$

a. Menyampaikan sebuah visi yang menarik

b. Menggunakan bentuk komunikasi yang kuat dan ekspresif saat mencapai visi itu

c. Mengambil resiko pribadi dan membuat pengorbanan diri untuk mencapai visi itu

d. Menyampaikan harapan yang tinggi

e. Memperlihatkan keyakinan akan pengikut

f. Pembuatan model peran dari perilaku yang konsisten dari visi tersebut

g. Mengelola kesan pengikut akan pemimpin

3. Tipe Pemimpin Karismatik

Pemimpin karismatik dikelompokkan menjadi dua tipe yaitu: ${ }^{221}$

a. Pemimpin karismatik visioner mengekpresikan visi bersama mengenai masa depan.

Melalui kemampuan komunikasi, pemimpin karismatik visioner mengaitkankebutuhan dan target dari pengikutnya dengan targaet atau tugas dariorganisasi. Mengaitkan para pengikut dengan target dari pengikut denganvisi, misi, dan tujuan organisasi akan lebih mudah jika mereka merasatidak puas atau tidak tertantang dengan keadaan pada saat ini. Pemimpinkarismatik visioner memiliki kemampuan

${ }^{220}$ Yukl, Kepemimpinan dalam Organisasi, (Jakarta : Index, 2005) h. 294

${ }^{221}$ Ivancevich, Perilaku dan Manajemen Organisasi (Jakarta : Erlangga, 2007) 
untuk melihat sebuah gambarbesar dan peluang yang ada para gambar besar tersebut.

b. Sementa tipe pemimpin karismatik di masa krisis akan menunjukkan pengaruhnya ketika system harus menghadapi situasi dimana pengetahuan, informasi, dan prosedur yang ada tidak mencukupi (Ian I. Mirtoff, 2004). Pemimpin jenis ini mengkomunikasikan dengan jelas tindakan apa yang harus dilakukan dan apa konsekuensi yang dihadapi.

4. Perilaku pemimimpin karismatik

Menurut Yukl (1994) pemimimpin karismatik memiliki perilaku-perilaku berikut ini, yaitu: ${ }^{222}$

a. Pemimpin karismatik memiliki perilaku yang dipercaya anggotanya bahwa pemimpin merupakan orang yang memiliki kompetensi sehingga semua keputusan yang diambil seorang pemimpin akanmemberikan kesan dan kepercayaan bagi anggotanya yang pada akhirnya anggota menjadi lebih patuh dan taat.

b. Pemimpin karismatik berperilaku yang lebih menekankan pada tujuantujuan ideologis yang berkaitan dengan tujuan bersama/kelompok berdasarkan nilai-nilai, cita-cita, serta aspirasiaspirasi anggotanya.

c. Pemimpin karismatik memiliki visi yang menarik mengenai gambaran masa depan organisasi sehinggga anggota menjadi memiliki ikatan emosional dan lebih termotivasi serta merasa pekerjaan yang dilakukannya bermakna, kemudian hal tersebut mendorong para anggota berkomitmen untuk mencapai tujuan yang telah ditetapkan.

${ }^{222}$ Ria Marginingsih, Kepemimpinan Karismatik Sebagai Employer Branding,Jurnal Bisnis Darmajaya, Vol.02. No.02 h. 32-51 
d. Pemimpin karismatik memberikan contoh perilaku agar para anggotanya mengikutinya. Ketika para anggota telah mengikutinya, pemimpin mampu memberikan pengaruh lebih karena anggota telah memiliki kesamaan keyakinan dan nilai-nilai, sehingga hal tersebut mengakibatkan kepuasan dan motivasi anggota menjadi lebih besar

e. Pemimpin karismatik akan mengkomunikasikan harapan-harapannya kepada anggota dan pada saat yang bersamaan pemimpin juga akan memberikan kepercayaan kepada anggotanya. Tujuan dilakukannya hal itu adalah agar anggota memiliki percaya diri sehingga anggota memiliki kinerja dan komitmen tinggi terhadap tujuan-tujuan yang telah ditetapkan

f. Pemimpin karismatik berperilaku yang dapat menimbulkan motivasi untuk pencapaian tujuan kelompok. Pemimpin karismatik memberikan motivasi dengan memberikan tugastugas yang kompleks, menantang, inisiatif, berisiko sehinggga anggota menjadi lebih bertanggung jawab dan tekun. Selain itu, untuk memberikan motivasi pemimpin karismatik juga memberikan wejangan atau pengetahuan yang dapat menginspirasi anggota dengan lebih menekankan pada nilai-nilai dan kesetiaan

\section{Kepemimpinan Karismatik}

Karisma dianggap sebagai kombinasi dari pesona dan daya tarik pribadi yang berkontribusi terhadap kemampuan luar biasa untuk membuat orang lain mendukung visi dan juga mempromosikannya dengan bersemangat. Teori atribusi ikut menjelaskan kepemimpinan karismatik memiliki kemampuan yang luar biasa. ${ }^{223}$

${ }^{223}$ Bob WawoRuntu, Determinan Kepemimpinan,Jurnal: Makara, Sosial Humaniora, VOL. 7, NO. 2, (2003), h. 71-81 
Pemimpin karismatik adalah pemimpin yang mewujudkan atmosfir motivasi atas dasar komitmen dan identitas emosional pada visi, filosofi, dan gaya mereka dalam diri bawahannya. ${ }^{224}$

Pemimpin karismatik mampu memainkan peran penting dalam menciptakan perubahan.Individu yang menyandang kualitas-kualitas pahlawan memiliki karisma. Sebagian yang lain memandang pemimpin karismatik adalah pahlawan.

The motivational effects of charismatic leadership are examined in greater detail. Charismatic leadership is assumed to have three core components: envisioning, empathy, and empowerment. A charismatic leader's envisioning behavior influences followers' needfor achievement, and the leader's empathic behavior stimulates followers' need for affiliation. Followers' need for power isenhanced by a charismatic leader's empowerment practices. ${ }^{225}$

Pemimpin karismatik menekankan tujuan-tujuan idiologis yang menghubungkan misi kelompok kepada nilai-nilai, cita-cita, serta aspirsiaspirasi yang berakar dalam yang dirasakan bersama oleh para pengikut.Selain itu kepemimpinan karismatik juga didasarkan pada kekuataan luar biasa yang dimiliki oleh seorang sebagai pribadi.Pengertian sangat teologis, karena untuk mengidentifikasi daya tarik pribadi yang melekat pada diri seseorang, harus dengan menggunakan asumsi bahwa kemantapan dan kualitas kepribadian yang dimiliki adalah merupakan anugerah tuhan.

Dalam kepemimpinan karismatik memiliki energi, daya tarik dan pembawa yang luar biasa untuk memengaruhi orang lain, sehingga ia mempunyai pengikut yang sangat besar jumlahnya dan pengawal-pengawal

${ }^{224}$ Ivancevich, John M, Human Resource Management, New York: Mc GrawHill, Tenth Edition. , 2007, h. 209

${ }^{225}$ Jaepil Choi, A Motivational Theory of Charismatic Leadership: Envisioning, Empathy, and Empowerment,Journal of Leadership and Organizational Studies, Vol. 13, No. 1 (2006) h. 25-43 
yang bisa dipercaya. Sampai sekarang pun orang tidak mengetahui benar sebab-sebabnya, mengapa seseorang itu memiliki karisma besar.Dia dianggap mempunyai kekuatan gaib (supranatural power) dan kemampuankemampuan yang superhuman, yang diperolehnya sebagai karunia yang mahakuasa. Dia banyak memiliki inspirasi, keberanian, dan berkeyakinan teguh pada pendirian sendiri.Totalitas kepribadian pemimpin itu memancarkan pengaruh dan daya tarik yang teramat besar.Tokoh-tokoh besar semacam ini, diantaranya Jengis Khan, Hitler, Gandhi, John F, Kennedy, Soekarno, Margaret Teacher, dan Gorbachev. ${ }^{226}$

Karena posisinya yang demikian itulah maka ia dapat dibedakan dari orang kebanyakan, juga karena keunggulan kepribadian itu, ia dianggap (bahkan) diyakini memiliki kekuasan supra natural, manusia serba istimewa atau sekurangkurangnya istimewa dipandang masyarakat.

House mengusulkan teori untuk menjelaskan kepemimpinan karismatik dalam hal sekumpulan usulan yang dapat diuji yang melibatkan proses yang dapat diamati bukannya cerita rakyat dan mistik. Teori itu mengenali bagaimana para pemimpin karismatik berprilaku, ciri dan ketrampilan mereka dan kondisi di mana mereka paling sering muncul.Shamir et.al telah merivisi dan memperluas teori itu dengan menggabungkan perkembangan baru dalam pemikiran tentang motivasi manusia dan gambaran yang lebih rinci tentang pengaruh pemimpin pada pengikut. Kepemimpinan karismatik dapat dipahami secara paling lengkap jika kita juga mempertimbangkan kemampuan faktor pemimpin dan situasional memengaruhi proses penyandangan ini. Hubungan khusus antara pemimpin karismatik dan pengikutnya tidak terjadi secara tidak sengaja, hubungan tadi sering kali merupakan hasil interaksi antara kualitas sang

${ }^{226}$ Op.cit. Machali, h. 89-90

152 
pemimppn, derajat sejauh mana visi pemimpin memenuhi kebutuhan pengikut, serta adanya faktor situasional tertentu. ${ }^{227}$

Tipe kepemimpinan karismatik dapat diartikan sebagai kemampuan menggunakan keistimewaan atau kelebihan sifat kepribadian dalam mempengaruhi pikiran, perasaan dan tingkah laku orang lain, sehingga dalam suasana batin mengagumi dan mengagungkan pemimpin bersedia berbuat sesuatu yang dikehendaki oleh pemimpin.Pemimpin disini dipandang istimewa karena sifat-sifat kepribadiannya yang mengagumkan dan berwibawa. Kepemimpinan kharismatik menginginkan anggota organisasi sebagai pengikutnya untuk mengadopsi pandangan pemimpin tanpa atau dengan sedikit mungkin perubahan.Pemimpin karismatik cenderung muncul di dunia politik, agama, saat perang, atau saat perusahaan masih dalam tahap awal atau menghadapi krisis yang mengancam kelangsungan hidupnya. Selain ideologi dan ketidakpastian, faktor situasional lain membatasi munculnya karisma di suatu level organisasi. Tetapi, visi biasanya berlaku untuk keseluruhan organisasi atau divisi-divisi utama. $^{228}$

Indonesia pernah memiliki pemimpin karismatik yang tidak kalah dibandingkan dengan tokoh-tokoh lainnya yaitu Soekarno.Pidato Soekarno merupakan suatu yang luar biasa. Pada setiap perayaan 17 Agustus, masyarakat sudah berada disekitar radio beberapa jam sebelum pidato presiden pertama Indonesia di mulai. Selama mendengar pidato Soekarno, hati masyarakat bergetar, bergairah, penuh semangat, dan merasa mau melakukan apa saja yang ia anjurkan. Ketika mereka tahu pidatonya akan

${ }^{227}$ Hughes, Ginnett, dan Curphy, Leadership memperkaya pelajaran dari pengalaman, (Jakarta: Salemba Humanika, 2012) h. 539-540

${ }^{228}$ Hurin In Lia Amalia Qori, Kepemimpinan Karismatik Versus Kepemimpinan Transformasional,Jurnal: Analisa, Vol. 1, No. 2, (2013) : h. 70-77 
segera berakhir, mereka merasa kecewa. Ingin rasanya Soekarno pidato sepanjang hari tanpa henti. ${ }^{229}$

Willner (1984) concluded that charismatic leadership was neither personality-based nor contextually-determined, but rather the phenomenon was largely relational and perceptual: "It is not what the leader is but what people see the leader as that counts in generating the charismatic relationship" (Willner, 1984, p. 14). Dow (1969) and Willner (1984) found that variations in individual personalities were too great to discern a single charismatic personality type and that the existence of a crisis-previously argued to be necessary for the emergence of charismatic leadership (Chinoy, 1961; Devereux, 1955; Downtown, 1973; Hummel, 1975; Schiffer, 1973)-was "neither a necessary nor a sufficient cause" (Willner, 1984, p. 60). ${ }^{230}$

Banyak orang berpendapat pemimpin karismatik memiliki bakat dari lahir.Mereka adalah orang-orang yang sangat beruntung karena memperoleh anugerah dari Tuhan berupa karisma. ${ }^{231}$ Hanya sedikit sekali orang yang memperoleh keberuntungan seperti itu.Namun, Robert J.Richardsondan S.Katharine Thayer bahwa karisma bukan anugerah dari lahir, karisma adalah bentuk komunikasi.Karisma merupakan bahasa komunikasi emosi. Karisma adalah kemampuan untuk menginspirasi orang lain agar dapat mengambil tindakan.

\section{Implikasi Kepemimpinan Karismatik Di Madrasah}

Beberapa penulis (Bryman, Schein, Trice \& Beyer) telah mengecam ide bahwa kepemimpinan karismatik merupakan sebuah obat mujarab untuk memecahkan masalah dari organisasi yang besar.Para kritikus menunjukkan beberapa alasan mengapa tidak selalu memungkinkan atau tidak selalu 89

${ }^{229}$ Subarto Zaini, Ladership in Action,(Jakarta: Elex Media Komputindo, 2011), h

${ }^{230}$ Jay A. Conger Rabindra , N. Kanungo. Toward A Behavioral Theory Of Charismatic Leadership In Organizational Settings,Journal Academy Ot Management Fleview, Vol. 12, No. 4, (1987). h. 637-647

${ }^{231}$ Ibid... h. 90 
diinginkan memiliki pemimpin karismatik yang menduduki posisi penting dalam organisasi sektor swasta dan publik.

Kepemimpinan karismatik itu berisiko. Tidaklah mungkin memprediksikan hasilnya saat orang memberikan terlalu banyak kekuasaan kepada seorang pemimpin dengan harapan yang sering kali tidak rasional agar ia akan benar-benar mampu memberikan sebuah visi masa depan yang lebih baikaekuasaan itu sering kali disalahgunakan sementara visi itu tetap menjadi mimpi yang kosong. Sejarah telah dipenuh oleh para pemimpin karismatik yang telah menyebabkan kematian yang tidak terhingga banyaknya, kehancuran, dan kesengsaraan dalam prosesnya membangun sebuah kerajaan, memimpin sebuah revolusi, atau mendirikan sebuah agama baru.

Kepemimpinan karismatik mengimplikasikan perubahan radikal dalam strategi dan budaya dari sebuah organisasi, yang mungkin tidak perlu atau tidak tepat bagi organisasi yang saat ini telah makmur dan berhasil.Sulit untuk membuat perubahan radikal dalam sebuah organisasi jika tidak ada krisis yang jelas. Jika terdapat sebuah koalisi yang kuat yang dipimpin oleh pemimpin karismatik yang memiliki visi yang bertentangan, organisasi dapat dirobek oleh konflik yang mengganggu. Cerita sejarah menyatakan bahwa banyak pemimpin karismatik merasa amat sulit menerapkan Visi radikal mereka dalam sebuah organisasi yang telah ada, dan mereka pergi untuk mendirikan sebuah organisasi baru (misalnya, sebuah bisnis baru, partai politik, atau pergerakan sosial yang baru).

Akhirnya, kebanyakan penelitian deskriptif menyatakan bahwa seorang pemimpin karismatik tidak perlu mencapai perubahan besar dalam sebuah organisasi Penelitian ini menemukan bahwa perubahan yang berhasil biasanya dihasilkan dari proses kepemimpinan transformasional bukan dari 
tindakan seorang pemimpin yang karismatik. Ada 5 tahapan kepemimpinan yang meliputi : ${ }^{232}$

a. Level 1, pemimpin yang mempimpin karena legalitas formal, misalnya memimpin karena surat keputusan (SK)

b. Level 2, pemimpin yang memimpin dengan kecintaannya, pemimpin pada level ini sudah memimpin orang, bukan memimpin pekerjaan

c. Level 3, pemimpin yang memiliki daya tarik luar biasa, pada pemimpin level ini, orang-orang ingin mengikutinya bukan karena apa yang telah diberika pemimpin secara personal atau manfaatnya, tetapi juga karena nilai-nilai dan simbol-simbol yang melekat pada diri orang tersebut.

Bila diamati, maka pemimpin yang memiliki tipe kepemimpinan kharismatik terletak pada level 3 pada teori Maxwell tersebut. Seorang pemimpin yang bertipe kharismatik pada lembaga pendidikan Islam, akan sangat efektif di dalam memimpin lembaga pendidikan tersebut. penerapan tipe kepemimpinan kharismatik di lembaga pendidikan Islam dapat dilakukan, dan mempunyai nilai yang positif. Keberhasilan tipe kepemimpinan kharismatik tersebut juga tidak lepas dari adanya nilai-nilai agama yang melekat pada lembaga-lembaga pendidikan Islam, sehingga tipe kepemimpinan kharismatik yang pada hakekatnya memang selalu identik dengan kepemimpin di bidang politik dan keagamaan.

\section{Manfaat bagi Madrasah}

Manfaat apa yang akan diperoleh oleh institusi madrasah dan segala komunitasnya ketika pimpinan secara taat asas mengaplikasikan kesepuluh kunci di atas? Dengan tetap melihat kemungkinan adanya manfaat lain, berikut ini disajikan manfaat esensial dari aplikasi sepuluh kunci dimaksud.

a. Improved Performance

${ }^{232}$ Muhaimin, et. al, Manajemen dan Kepemimpina Sekolah/ Madrasah, (Jakarta:Kencana Prenada Media Group,2010) h. 30 
Peningkatan kinerja bagi madrasah berarti tejadi perbaikan mutu proses dan hasil belajar. Dalam jangka panjang hal ini akan mendorong animo masyarakat menyekolahkan anaknya ke madrasah itu. Bagi guru dan kepala sekolah hal itu juga berarti akan menjadi mampu bekerja dalam anggaran terbatas. Bagi pemangku kepentingan madrasah berarti hal itu mampu memenuhi bahkan melampaui standar yang ditetapkan oleh mereka.

b. Reduced Conflict

Berkurangnya konflik "berarti memungkinkan komunitas madrasah lebih sedikit melanggar perundang-undangan, kurang klaim dari guru dan staf.Juga, guru dan staf menjadi lebih bertoleransi antarsesama "mereka, termasuk dengan pimpinannya.

c. Motivated Staff

Termotivasinya staf berarti akan ada penularan motivasi dan semangat kerja. Ketika itu pula semua komunitas madrasahakan suka melihat orang tersenyum bahagia, bukan sengsara, merengut, menggerutu, mencela, bahkan meradang.

\section{d. Reduction in Costs}

Pengurangan biaya bermakna bisa bekerja secara ekonomis, apa pun dilaksanakan dengan biaya yang lebih rendah. Staf akan lebih berbahagia dan cenderung tidak menyalahgunakan tasilitas dan hak-hak mereka sesuai dengan kapasitas madrasah.

\section{Kesimpulan}

Kepemimpinan adalah kemampuan seseorang guna mempengaruhi, memotivasi, dan mengaktivasi aneka potensi dan sumber daya yang ada, sehingga organisasi yang dipimpinnya mampu berjalan secara efektif dalam rangka mengupayakan perwujudan tujuan-tujuannya. 
Pemimpin karismatik adalah pemimpin yang mewujudkan atmosfir motivasi atas dasar komitmen dan identitas emosional pada visi, filosofi, dan gaya mereka dalam diri bawahannya dan mampu memainkan peran penting dalam menciptakan perubahan.

Keberhasilan tipe kepemimpinan kharismatik tersebut juga tidak lepas dari adanya nilai-nilai agama yang melekat pada lembaga-lembaga pendidikan Islam, sehingga tipe kepemimpinan kharismatik yang pada hakekatnya memang selalu identik dengan kepemimpin di bidang politik dan keagamaan.

\section{Referensi}

Alfian, M. Alfan. Menjadi Pemimpin Politik. Jakarta: Gramedia Pustaka Utama, 2009.

Choi, Jaepil A Motivational Theory of Charismatic Leadership: Envisioning, Empathy, and Empowerment,Journal of Leadership and Organizational Studies, 2006, Vol. 13, No. 1 hlm.25-43

Danim, Sudarwan , Kepemimpinan Pendidikan, Bandung: ALFABETA,2010.

G.Northouse, Peter, Kepemimpinan Teori dan Praktik, Jakarta:Indeks,2016.

Hughes, Ginnett, dan Curphy, Leadership memperkaya pelajaran dari pengalaman, Jakarta: Salemba Humanika, 2012

In Lia Amalia Qori, Hurin, Kepemimpinan Karismatik Versus Kepemimpinan Transformasional, Jurnal: Analisa, Vol. 1, No. 2,(2013) : 70-77

Ivancevich, dan John M, Human Resource Management, New York: Mc Graw-Hill, Tenth Edition., 2007.

Ivancevich, Perilaku dan Manajemen Organisasi, Jakarta : Erlangga, 2007. 
Jay A. Conger Rabindra , N. Kanungo. Toward A Behavioral Theory Of Charismatic Leadership In Organizational Settings,JournalAcademy Ot Management Fleview., Vol. 12, No. 4 (1987) 637-647

Machali, Imam dan Ara Hidayat, The Handbook of Education Managemant, Jakarta: Perdana Grup, 2016.

Marginingsih, RiaKepemimpinan Karismatik Sebagai Employer Branding,Jurnal Bisnis Darmajaya, Vol.02. No.02, (2016) 32-51

Muhaimin, et. al, Manajemen dan Kepemimpina Sekolah/Madrasah, Jakarta : Kencana Prenada Media Group,2010.

RL, Green, Practicing the Art of Leadership : Problem based Approach to Implementing The ISLLC Standars Colombus, Ohio: Merrill Prentice Hall, 2001.

Safaria, Triantoro Kepemimpinan, Yogyakarta:Graha Ilmu,2004.

Soekanto, Soerjono, Sosiologi Suatu Pengantar Jakarta: Raja Grapindo Persada, 2006.

Syafaruddin, Manajemen Lembaga Pendidikan Islam Jakarta: PT.Ciputat Press, 2005.

Syafrida, Kepemimpinan Kepala Sekolah, Manajer Pendidikan, Volume 9, Nomor 5,( 2015.)hlm 679-685

Tony Bush, Educational leadership and management: theory, policy, and practice, South African Journal of Education, Vol 27(3)391-406 